\title{
Sports Teacher Perception about Lake Sipin Sport Tourism Area in Jambi City
}

\author{
Ugi Nugraha*, Moch. Asmawi, Hidayat Humaid, Firmansyah Dlis \\ Physical Education, State University of Jakarta, Indonesia
}

Received March 24, 2020; Revised June 23, 2020; Accepted July 20, 2020

\begin{abstract}
Cite This Paper in the following Citation Styles
(a): [1] Ugi Nugraha, Moch. Asmawi, Hidayat Humaid, Firmansyah Dlis , "Sports Teacher Perception about Lake Sipin Sport Tourism Area in Jambi City," International Journal of Human Movement and Sports Sciences, Vol. 8, No. 4, pp. 103-109, 2020. DOI: 10.13189/saj.2020.080401.
\end{abstract}

(b): Ugi Nugraha, Moch. Asmawi, Hidayat Humaid, Firmansyah Dlis (2020). Sports Teacher Perception about Lake Sipin Sport Tourism Area in Jambi City. International Journal of Human Movement and Sports Sciences, 8(4), 103-109. DOI: $10.13189 /$ saj.2020.080401

Copyright $\bigcirc 2020$ by authors, all rights reserved. Authors agree that this article remains permanently open access under the terms of the Creative Commons Attribution License 4.0 International License

\begin{abstract}
Purpose: This study aims to determine the perception of sports teachers about the Sipin Lake area which is used as Sport Tourism in Jambi City. Because making an object in an area that can be used as a sports area and a place of tourism can boost various fields, like in the field of sports, tourism, and education. Methodology: Using Mixed Methods. Where, the number of samples in this study was as many as 108 teachers who were around the area of Lake Sipin Sport Tourism in Jambi City using the Purposive Sampling technique. The instruments used were teacher perception questionnaire and semi-structured interviews. Data were then analyzed with the help of the SPSS 21 application to find descriptive statistics in the form of Mean, Min, Max, and category, and use interviews and documentation to strengthen the quantitative data that have been obtained through the questionnaire provided. Findings: The results of this study found that teachers have good perception, which is indicated by a dominant good result of $68.2 \%$ teachers, according to them by making Lake Sipin a Sport Tourism area will make students motivated to become rowing athletes who can make the school name even the region. Contribution and Recommendation: This research contributes to all elements, both sports, tourism, and education, by making the Sipin Lake object as sport tourism.
\end{abstract}

Keywords Lake Sipin, Perceptions, Sport Tourism, Teachers

\section{Introduction}

Education is everything in life that affects the formation of thinking and acting of an individual. Education is an endless process that is sought by anyone, especially (as the responsibility) of the state. Therefore it is regulated by Law No. 20 of 2003 that education is an activity that can develop a student's potential in thinking critically and creatively. Providing maximum education to students will create quality students [1-2]. As it is known that, education is a process to acquire and instill the skills performed by students [3-7]. Education in Indonesia is divided into several levels. However, at each of these levels, there must always be lessons in recreational sports at every level. Like a developing field of scientific study, sports-tourism researchers have dedicated a significant amount of their energy to clarifying the conceptual foundations of this field. The prominent position of these concepts in sport implies the dynamics of travel which to date has been largely ignored by scholars in tourism and sports. But the closeness between sports and tourism cannot be ignored by the traveling community or by the vibrant industry that has emerged in response to this demand.

Recreational sports is a sports activity that is carried out during leisure time so that the performer gets emotional satisfaction such as pleasure, excitement, happiness, and obtains physical-physiological satisfaction such as maintaining health and fitness so that overall health is achieved. Recreation is a sport carried out by people with a passion and ability that grows and develops following the conditions and cultural values of the local community for 
health, fitness, and excitement [8-11]. Sports Recreation is carried out by people with a passion and ability to grow and develop following the conditions and cultural values of the local community for health, fitness, and excitement. The scope of recreational sports in the Law on the National Sports System is explained in Article 19, as follows: (1) Recreational sports are carried out as part of the process of restoring health and fitness. (2) Recreational sports can be carried out by anyone, education unit, institution, association, or sports organization. (3) Recreational sports as referred to in paragraph (1) aim to a. gain health, physical fitness, and excitement; b. building social relations; and/or c. preserving and increasing regional and national cultural wealth. (4) The government, regional government, and the community are obliged to explore, develop and promote recreational sports. (5) Every person who organizes certain recreational sports that carry risks to environmental sustainability, maintenance of facilities, as well as safety and health must: a. obey the rules and procedures set according to the type of sport; and $b$. provide instructors or guides who have the knowledge and skills according to the type of sport. (6) Recreational sports as referred to in paragraph (5) must meet the requirements set by sports associations or organizations [12].

The existence of recreational sports is carried out by the government, making income/income to the region in terms of tourism because by implementing a tourist destination that can be used as recreation and exercise can improve the regional economy that implements it. The relationship between Sports and Tourism is gaining momentum in industry and academia. The reasons for this sudden interest seem to originate from five basic directions [13-15]. First, the popularity of international and national sporting events has increased significantly such as the Olympics, Asian Games, and Sea Games. Second, there is a broader understanding of the health-related benefits that can be achieved through active participation in many sports. Third, the government and leaders began to appreciate the value of sports about the economy and national and international relations. Fourth, there are a variety of wider and carefully programmed sporting events offered throughout the year; facilitate the audience and participants. Finally, sports-minded individuals are not only more mobile but can also communicate more effectively due to improved technology and global infrastructure.

The concepts of tourism and sports are interrelated and overlapping. Sport is an important activity in tourism and tourism is a basic characteristic of the sport. The specific meeting of these two concepts varies regarding the perspectives of those who deal with the topics and definitions they adopt. Sport is generally positioned as a major travel activity, although Gammon and Robinson make the difference between sports tourists and sports tourism [16]. The latter recognizes sport as a secondary activity when traveling. Sports tourism is defined as sports-based travel away from the home environment for a limited time, where sports are characterized by a unique set of rules, competition related to physical prowess, and pleasant nature. This definition parallels the structure underlying most definitions of tourism in terms of spatial, temporal and activity dimensions with the difference being that the dimensions of activity are determined as sports [17-20].

Sport is recognized as a significant travel activity in both the main and secondary features of the trip. This is seen as an important factor in many decisions to travel, often stand out in travel experiences and is often an important consideration in visitor ratings of travel experiences. Sports tourism is further clarified about previous discussions about the sports domain. First, each sport has its own set of rules that provide a unique spatial and temporal structure. Second, competition related to physical prowess is a consolidation of what is described as goal orientation, competition, and contest-based sports aspects. This is used here in the broadest sense to indicate the continuum of competition including what is often considered a recreational sport or 'sport for all' [21-23]. Finally, exercise is characterized by its pleasant nature. This element includes the idea of the uncertainty of the results and views agreed upon. In the more competitive sports version, therefore, many types of sports involvement can be carried out by sports tourists. Besides, it can also be an arena for coaching athletes rowing, because the sports tour referred to here is sipin lake tourism in the middle of urban areas.

Achievements in the field of sports can lift the good name of schools, regions and make the name of the nation and country among the hundreds in the world. Competition in sports performance is increasingly stringent nowadays. Achievement is no longer the property of individuals, but it concerns the dignity and dignity of a nation. That is why various powers and efforts are made by a school or region, or the country to place its athletes as champions in major sports activities. Sports coaching is an important stage in achieving sports achievements. The system of fostering sports achievements in Indonesia is scouting talent and developing talent. So, to achieve a high level of achievement, a good coaching system is needed. Without coaching that is systematically maximized, the achievement stage will not be achieved [24-25]. High achievement in a sport, requires prerequisites in the form of characteristics following the demands of the sports concerned. Because each branch of sport has a specific nature and therefore also sports coaching is deliberate and systematic assistance to meet these demands to achieve higher achievements. One effort that can be made to improve sports performance, especially rowing, is by developing sports associations through coaching and training centers [26].

One of the best ways to foster a positive mental attitude is through activities that fill their free time, namely arts, sports and recreation in that activity they can channel their respective talents. Recreation has an impact to create or regain a balance between physical, spiritual, emotional, and social so that it can obtain freshness, enthusiasm, new 
enthusiasm and if directed properly will increase knowledge, increase the love of the motherland and admire the creation of God Almighty. One of the potentials that can be developed and become a mainstay for economic development is from the Tourism sector [27-28]. For Indonesia, the role of tourism is increasingly felt, especially after the weakening role of oil and gas. Indonesia's natural potential can be an alternative in helping the economy for the community, for example through the development of recreational tourism, especially recreational sports.

Especially in the sipin lake area, which has long been used as an economic center by the people around Lake Sipin, such as making sprouts for fish, shrimp, etc. However, the government sees a good opportunity in the Sipin Lake, which can be used as a place for recreation and sports, such as rowing, sky, dragon boats, and even at the Sipin lake there has been a national dragon boat race event held at the venue.

At this time, recreational tourism is increasingly advanced so that many sports fields that are now used as objects and attractions for tourists organizing recreational sports tourism will directly bring benefits in several fields such as economics, expanding the values of social life and knowledge, arts and culture, maintenance and environmental use, and can provide benefits for the surrounding community because it can open business opportunities such as the provision of food, beverages, transportation businesses both traditional and conventional and others [29-31].

Therefore, the purpose of this study is to look at the perception of sports teachers about sports tourism lake sipin Jambi around their schools in Jambi province Indonesia.

The question in this research is, what kind of perception do sports teachers have about the Sipin Lake Sports Tourism area?

\section{Materials and Methods}

\subsection{Research Design}

This research uses a mixed-methods approach. Mixed methods can refer to the use of quantitative and qualitative data in answering research questions and being part of a larger research program and designed as a complement to provide information related to different methodological approaches [32]. The type used is sequential explanatory. Sequential An explanatory research is a study where the initial data collection is quantitative which is then followed by qualitative data, which means that quantitative data is strengthened by the qualitative data that will be obtained [33].

\subsection{Research Subject}

Where, quantitative data were obtained through giving perception questionnaires to teachers, then followed by qualitative activities namely conducting interviews. This study used 108 teachers located around Sipin Lake in Jambi City using a total sampling technique with details of 78 male teachers and 30 female teachers. The total sampling technique is an example of a collection technique that uses the whole of a population [34], then interviews all samples in this study. The instruments in this study used questionnaires and interviews. The questionnaire is a list of questions given to other people who are willing to answer (respondents) according to user requests [35].

\subsection{Research Instrument}

In sequential explanatory research, researchers have instruments, for quantitative aspects, namely, perception questionnaire. Then for the qualitative aspects of the instrument using interviews and documents.

In the first data collection process, because it uses the type of sequential explanation, the first data obtained is quantitative data through the teacher's perception questionnaire about sports tourism lake sipin. The perception questionnaire was tested by experts and obtained as many as 26 valid statements with a Cronbach alpha value of 0.75 , wherein, the perception questionnaire used a Likert Scale of 4 (four), i.e. for positive statements strongly disagree having a Score of 1, disagreeing to has a score of 2, agrees to have a score of 3 and strongly agrees 4 . Then conducts a semi-structured interview to confirm the quantitative results that have been carried out. For data processing, using SPSS 21 which is intended to find descriptive statistics to view quantitative data, while for qualitative data using miles \& huberman, namely reducing data, displaying data, and conclusions [36]. Descriptive statistics are presented in summary frequencies, such as mean, mode, median, minimum, maximum and standard deviation [34]. In this study the descriptive statistics used are mean, min, max, and Category. During data collection, the first activity that must be done is to select students based on the categories provided by the researcher, then give questionnaire of teacher perception for sports tourism, the questionnaire is then processed using SPSS 21 application data to see descriptive statistics, in the form of, the mean, min, max, percentage, and category of teachers. Below is a category of the perception teacher to sports tourism, among others, very good, good, not good, and very not good, like table 1 below:

Table 1. Categories of Perception Teachers about Sport Tourism Sipin Lake

\begin{tabular}{cc}
\hline Category & Interval \\
\hline Very Not Good & $26.0-45.5$ \\
Not Good & $45.6-65.0$ \\
Good & $65.1-84.5$ \\
Very Good & $84.6-104.0$ \\
\hline
\end{tabular}


The second data collection is conducting interviews and documentation of sporting activities in Lake Sipin to attract tourists in search of entertainment. Interviews use semi-structured to get the desired results.

Documentation in this study includes photos of sports activities in Sipin in attracting tourists. Interviews and documentation were analyzed using miles \& Huberman namely, reduction, display and conclusion [36]. The procedure for collecting and analyzing data can be seen in Figure 1 below.

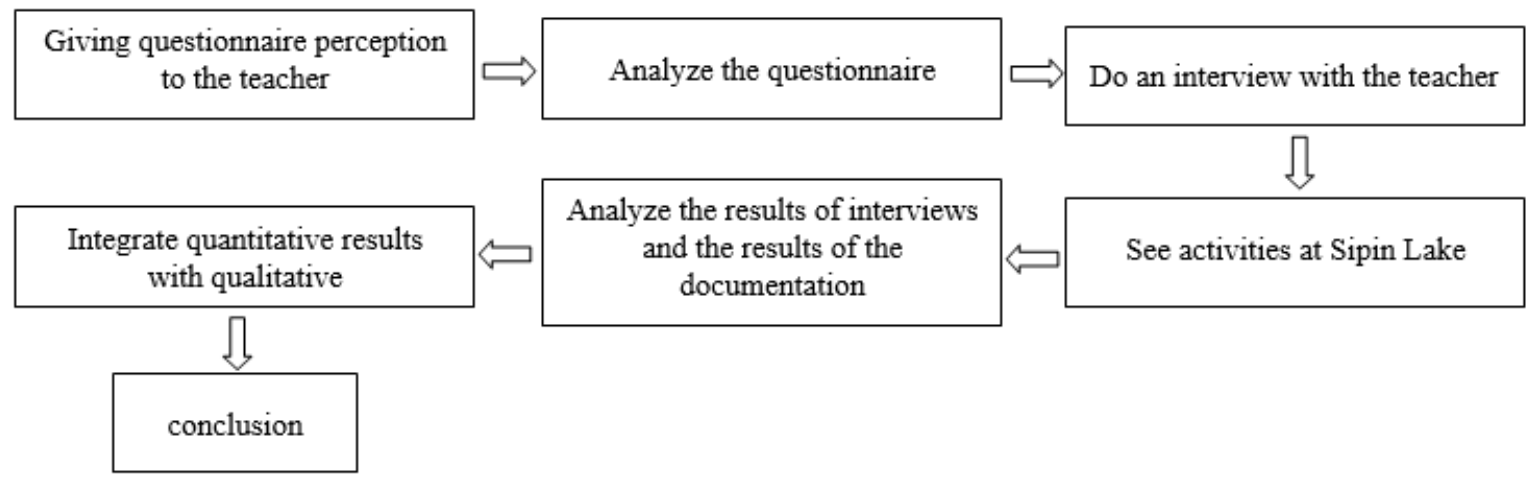

Figure 1. Data Collection

Table 2. Results from teacher perception of sport tourism

\begin{tabular}{|c|c|c|c|c|c|c|c|c|}
\hline \multicolumn{5}{|c|}{ Classification } & \multirow{2}{*}{ Mean } & \multirow{2}{*}{ Min } & \multirow{2}{*}{$\operatorname{Max}$} & \multirow{2}{*}{$\%$} \\
\hline Range & Respond & M & $\mathbf{F}$ & Total & & & & \\
\hline $26.0-45.5$ & Not very good & 0 & 0 & 0 & \multirow{4}{*}{76.2} & \multirow{4}{*}{30} & \multirow{4}{*}{97} & 0.0 \\
\hline $45.6-65.0$ & Not good & 4 & 5 & 9 & & & & 8.3 \\
\hline $65.1-84.5$ & Good & 63 & 15 & 78 & & & & 72.2 \\
\hline $84.6-104.0$ & Very good & 11 & 10 & 21 & & & & 19.5 \\
\hline TOTAL & & 78 & 30 & 108 & & & & 100 \\
\hline
\end{tabular}

\subsection{Analyze Data}

All data were obtained from the perception questionnaires on teachers' values and collected with the SPSS 21 application. Descriptive statistics are given to calculate the frequency, percentage, mean, min, and max of a sample (Creswell, 2012). As well as analyzing qualitative data obtained using miles \& Huberman, namely subtracting data, displaying data, and concluding (Miles \& Huberman, 1994).

\section{Results and Discussion}

To answer the research questions that have been mentioned can be seen in table 2 above.

From table 2, which came from 22 respondents from sports teachers who were around the Sipin Lake water tourism area were categorized both for men as many as 10 teachers and women as many as 5 teachers in the good category, and after being processed and obtained the results using the SPSS 21 application program, found for teacher perceptions of sport tourism in the lake sipin has a good category of $68.2 \%$ for 15 teachers out of 22 total teachers, not good at $9.1 \%$ for a total of 2 teachers out of 22 total teachers, and very good $22.7 \%$ for 5 teachers out of 22 total teachers. Of the 22 sports teachers, the Mean value of 76.2, a Maximum Value of 97, and a Minimum Value of 30.

Judging from the results that have been obtained the concepts of tourism and sports are interrelated and overlapping and have an effect on education, this can be proven by the results of teachers' perceptions of sport tourism having a good category of $68.2 \%$, and this is reinforced by the results of interviews that have been done the following.

"In your opinion, how is the program from the government that promotes sport tourism in Jambi City Sipin Lake?"

"I agree and support the program proposed by the city government regarding the making of Sipin Lake as a sports tourism area, which can encourage the community's economy and be able to become a place to educate students through recreational sports".

"Meaning, for you sport tourism also affects the students you teach?"

"Yes, that's right, in addition to being a place to educate students, Lake Sipin sports tourism can also make training centers for prospective athletes and athletes in the city of Jambi City".

If one of your students enters the training center to become a rowing athlete representing the City of 
Jambi, even Indonesia, what will you do?

"I will fully support, even recommend the child in reaching his dreams/ideals or goals, besides, he will make the name of the school, region, and country better than before".

Sport is an important activity in tourism and tourism is a basic characteristic of the sport. Special meetings of these two concepts vary regarding the perspectives of people who deal with the topics and definitions they adopt. Sport is recognized as a significant travel activity both in the main and secondary features of the trip. This is seen as an important factor in many decisions to travel, often stand out in travel experiences, and is often an important consideration in visitor ratings of travel experiences. In the more competitive sports version, one of the basic goals is that competitors must be compared, so the results are uncertain. Therefore, many types of sports involvement can be carried out by sports tourists [37-39].

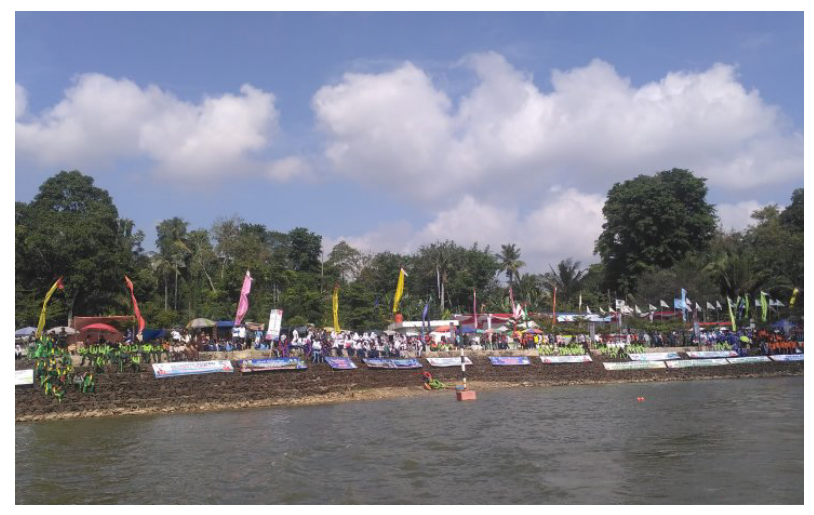

Figure 1. The enthusiasm of the Jambi City Community in seeing the National level competition held at Lake Sipin

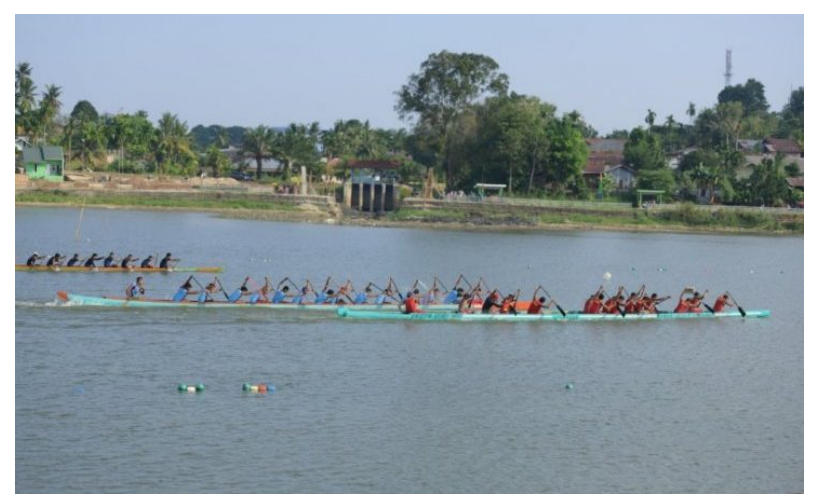

Figure 2. The race is ongoing

It can be seen from figures $1 \& 2$ that by being made a place, not only can it be used as a place to exercise, but also be able to invite people to relaxation there.

One of them is Sipin Lake, which is used as a superior spot for people to relax and exercise, especially rowing. Not only the potential in the water, but the area around Sipin Lake is also very possible for the development of outbound areas and other recreational facilities. The natural beauty of Lake Sipin is the main attraction for visitors to come, by making Lake Sipin a leading tourist attraction in the city of Jambi, which is expected to make the image of tourism in the city of Jambi better. Seeing the existing natural potential of the local community is very supportive of the development of the Sipin Lake natural attractions. Through this, the city government has made a program in the development of the Sipin Lake attractions, one of which is the creation of fish ponds for breeding freshwater fish in Sipin Lake, boat engines for visitors, the creation of play facilities for children. Besides, the Government together with the local community will build a special fishing area. Jambi City Government is very open to private parties who want to work together in the development of Sipin Lake attractions, such as the development of water sports and the development of an outbound area.

Sport is a worldwide phenomenon and an inseparable part of daily life. So that sport becomes a strategic means to build self-confidence, national identity, and national pride [40-42]. Share development progress in the field of sports that boils down to increase cultural and sporting achievements. Through systematic sports coaching, the quality of human resources can be directed at improving self-control, responsibility, discipline, sportsmanship, which in turn can obtain sporting achievements that can arouse national pride [43]. Therefore, sports development needs to get more proportional attention through coaching, management, planning and systematic implementation in national development. In addition to being a tourist attraction, Sipin Lake can also be a training center of the paddle athletes of the City of Jambi in particular, because having achievements in the field of sports can elevate the good name of schools, regions and make the name of the nation and country among hundreds around the world. Competition in sports performance is increasingly stringent nowadays. Achievement no longer belongs to individuals, but it concerns the dignity and dignity of a nation. That is why a variety of power and efforts are made by a school or region, or country to place its athletes as champions in major sporting activities [44]. Sports coaching is an important stage in achieving sports achievements. The system of fostering sports achievements in Indonesia is scouting talent and developing talent. So, to achieve a high level of achievement, a good coaching system is needed. Without coaching that is systematically maximized, the achievement stage will not be achieved [45]. High achievement in a sport, requires prerequisites in the form of characteristics following the demands of the sports concerned. Because each branch of sport has a specific nature and therefore also sports coaching is deliberate and systematic assistance to meet these demands to achieve higher achievements. One effort that can be made to improve sports achievements, especially rowing, is by developing sports associations through coaching and training centers. 


\section{Conclusions}

With program carried out by the city government regarding sports tourism in Lake Sipin, it will affect the local economy and can make the surrounding communities and schools around Lake Sipin affected. One of them can arouse the enthusiasm of students who are in school to participate as rowing athletes whose training camp is in Lake Sipin. As well as sports teachers fully support the implementation of the program because it can improve the regional economy and make a good school name through participating students who become rowing athletes. However, it requires synergy between the elements in order to realize the implemented program. In addition to this, the sport tourism site in Lake Sipin is still newly implemented so that it can still be explored even greater about the potential contained in Lake Sipin, one of the potentials such as that which has been held, namely the dragon boat race and traditional, but it was only until at the national stage it has not yet reached the international stage (Asean, Asia, and the World).

Teachers' perceptions of sport tourism, supporting sport tourism, therefore direct children to become children, despite the lack of assistance. Why because in the current curriculum, it is not enough for the teacher to only provide learning, but the teacher must be able to become a motivator and trainer with existing limitations.

\section{Acknowledgments}

Thanks to the whole school principal who has permitted me to research his school. And all the teachers who helped during the study.

\section{REFERENCES}

[1] Budiarti, R. S., Harlis., Natalia, D. High Oder Thinking Skills for Biology Education: Applied Microbiology Learning Videos Based on Jambi Local Wisdom. Universal Journal of Education Research, 8(2), 689-694. 2020

[2] Maison., Darmaji., Astalini., Kurniawan, D. A., Sumaryanti., Perdana, R. Supporting Assessment in Education: E-Assessment Interest in Physics. Universal Journal of Education Research, 8(1) 89-97, 2020.

[3] Astalini, Kurniawan, D. A., Darmaji, Sholihah, L. R., Perdana, R. Characteristics of Students' Attitude to Physics in Muaro Jambi High School. Humanities \& Social Science Reviews (HSSR), 7(2), 91-99, 2019.

[4] Asrial., Syahrial., Kurniawan, D. A., Chan, F., Septianingsih, R., Perdana, R. Multimedia Innovation 4.0 in Education: E-Modul Ethnoconstrucivism. Universal Journal of Educational Research. 7(10), 2098-2107, 2019.

[5] Darmaji., Kurniawan, D. A., Astalini., Lumbantoruan, A., \&
Samosir, S. C. Mobile Learning in Higher Education for The Industrial Evolution 4.0: Perception and Response of Physics Practicum. International Journal of Interactive Mobile (IJIM), 13(9), 4-20, 2019.

[6] Kurniawan, D. A., Asrial., Syahrial., Salsabila, W. S., Kurniawati, E. F., Anandari, Q. S., Perdana. R., Lumbantoruan, A., Nasih, N., Samosir, S. C., Dewi, U. P. Ethnoscience Investigation in Primary Schools: Impact on Science Learning. Universal Journal of Educational Research. 7(12), 2789-2795. 2019.

[7] Maison., Astalini., Kurniawan, D. A., Perdana, R., Anggraini, L. The Phenomenon of Physicology Senior High School Education: Relationship of Students' Attitudes towards Physics, Learning Style, Motivation. Universal Journal of Educational Research. 7(10), 2199-2207, 2019.

[8] D. Gilbert \& S. Hudson, 'Tourism Demand Constraints: A Skiing Participation', Annals of Tourism Research, 27(4), 906-25. 2000

[9] T.D. Hinch and J.E.S. Higham, 'Sport Tourism: A Framework for Research', The International Journal of Tourism Research, 3(1), 45-58, 2001.

[10] B. McKercher \& A. Lew, 'Distance Decay and the Impact of Effective Tourism Exclusion Zones on International Travel', Journal of Travel Research, 42(2), 159-65, 2003.

[11] Hinch, T., Jackson, E. L., Hudson, S., \& Walker, G. (2005). Leisure Constraint Theory and Sport Tourism. Sport in Society, 8(2), 142-163.doi:10.1080/17430430500087435

[12] Undang-Undang Republik Indonesia Nomor 3 Tahun 2005 Tentang Sistem Keolahragaan Nasional

[13] Kurtzman, J. Sports tourism categories revisited. Journal of Sport Tourism, 2(3), 6-11, 1995

[14] Lockstone, L., \& Baum, T. Fun in the family: tourism and the Commonwealth Games. International Journal of Tourism Research, 10(6), 497-509, 2008. doi:10.1002/jtr.7 01

[15] Ritchie B, Adair D. The growing recognition of sport tourism. Current Issues in Tourism 5: 1-6, 2002.

[16] Gammon, S., \& Robinson, T. Sport and tourism: A conceptual framework. Journal of Sport Tourism, 4(3), 11-18, 1997.

[17] Torres-Delgado, A., \& Palomeque, F. L. Measuring sustainable tourism at the municipal level. Annals of Tourism Research, 49, 122-137, 2014. https://doi.org/10.10 16/j.annals.2014.09.003

[18] Sinclair-Maragh, G., Gursoy, D., \& Vieregge, M. Residents' perceptions toward tourism development: A factor-cluster approach. Journal of Destination Marketing \& Management, 4(1), 36-45, 2015. https://doi.org/10.1016/j.jdmm.2014.10. 001

[19] Tanguay, G. A., Rajaonson, J., \& Therrien, M.-C. Sustainable tourism indicators: Selection criteria for policy implementation and scientific recognition. Journal of Sustainable Tourism, 21(6), 862-879, 2013. https:// doi.org/10.1080/09669582.2012.742531

[20] Vučetić, A. Š. Importance of environmental indicators of sustainable development in the transitional selective tourism 
destination. International Journal of Tourism Research, 20(3), 317-325, 2018. doi:10.1002/jtr.2183

[21] Rudež, H. N., Sedmak, G., \& Bojnec, Š. Benefit segmentation of seaside destination in the phase of market repositioning: The case of Portorož. International Journal of Tourism Research, (15), 138-151, 2013. https://doi.org/10.1002/jtr.881

[22] Long, J., Vogelaar, A., \& Hale, B. W. Toward sustainable educational travel. Journal of Sustainable Tourism, 22(3), 421-439, 2014. https://doi.org/ 10.1080/09669582.2013.81 9877

[23] Roe, P., Hrymak, V., \& Dimanche, F. Assessing environmental sustainability in tourism and recreation areas: A risk-assessment-based model. Journal of Sustainable Tourism, 22(2), 319-338, 2014. https://doi.org/ $10.1080 / 09669582.2013 .815762$

[24] Boyle, R., \& Haynes, R. Power play: Sport, the media and popular culture. London: Pearson Education, 2000

[25] Gammon, S., Ramshaw, G., \& Waterton, E. Examining the Olympics: Heritage, identity and performance. International Journal of Heritage Studies, 19(3), 119-124, 2012. Retrieved from http:// dx.doi.org/10.1080/13527258.2012.6 87395

[26] Hinch, T., \& de la Barre, S. Sporting events as tourist attractions in Canada's Northern periphery. In D. K. Muller and B. Jansson (Eds.), Tourism in peripheries: Perspectives from the far North and South (pp. 190-201). Wallingford: CABI, 2007.

[27] Das, M., \& Chatterjee, B. Ecotourism: A panacea or a predicament? Tourism Management Perspectives, 14, 3-16, 2015. https://doi.org/10.1016/j. tmp.2015.01.002

[28] Loperena, C. A. Conservation by racialized dispossession: The making of an eco-destination on Honduras's North Coast. Geoforum, 69, 184-193, 2016.https://doi.org/10.101 6/j.geoforum.2015.07.004

[29] Jamal, T., \& Camargo, B. A. Sustainable tourism, justice and an ethic of care: Toward the just destination. Journal of Sustainable Tourism, 22(1), 11-30, 2014.https://doi.org/10. $1080 / 09669582.2013 .786084$

[30] Franzoni, S. Measuring the sustainability performance of the tourism sector. Tourism Management. Perspectives, 16, 22 27, 2015. https:// doi.org/10.1016/j.tmp.2015.05.007

[31] Duh, M., Belak, J., \& Milfelner, B. The importance of culture for enterprise dynamics: The role of type and strength of the culture. Economic Research-Ekonomska Istra ž ivanja, 29(1), 263-285, 2016. https://doi. org/10.1080/1331677x.2016.1168038
[32] D. M, Martens. Research and Evaluation in Education and Psychology Integrating Diversity with Quantitative, Qualitative, And Mixed Methods. Singapore: SAGE Publications Asia-Pacific 2010.

[33] J. W, Creswell. Research Design Qualitative, Quantitative, And Mixed Method Aproach. Singapore: SAGE Publications Asia-Pacific, 2012.

[34] F. N, Kerlinger. Foundations of behavioral research Yogyakarta: Gadjah Mada, 2014.

[35] L. Cohen., L. Manion., \& K. Morrison. Research Methods In Education: Routledge. 2007

[36] M. B, Miles., \& A. M, Huberman. Qualitative data analysis (2nd ed.). Thousand Oaks, CA: Sage. 1994

[37] Kiss, K. The challenges of developing health tourism in the Balkans. Tourism: An International Interdisciplinary. Journal, 63(1), 97-110, 2015.

[38] Boukas, N., \& Ziakas, V. Tourism policy and residents' wellbeing in Cyprus: Opportunities and challenges for developing an inside-out destination management approach. Journal of Destination Marketing \& Management, 5(1), 44 54, 2016. https://doi.org/10.1016/j.jdmm.2015. 12.004

[39] Lee, S., \& Bai, B. Influence of popular culture on special interest tourists' destination image. Tourism Management, 52, 161-169, 2016. https://doi.org/10.1016/j.tourman.2015. 06.019

[40] Ramshaw, G., \& Hinch, T. Place identity and sport tourism: The case of the heritage classic ice hockey event. Current Issues in Tourism, 9(4\&5), 399-418, 2006.

[41] Hinch, T., \& Ramshaw, G. Heritage sport tourism in Canada. Tourism Geographies, 16(2), 237-251, 2014. doi:10.1080/14616688.2013.823234

[42] White, L. Cathy Freeman and Australia's indigenous heritage: A new beginning for an old nation at the Sydney 2000 Olympic Games. International Journal of Heritage Studies, 19(2), 153-170, 2012. http://dx.doi.org/10.1080/13 527258.2012 .670127

[43] Anton, M., Garrett, B. L., Hess, A., Miles, E., \& Moreau, T. London's Olympic waterscape: Capturing transition. International Journal of Heritage Studies, 19(2), 125-138, 2012. Retrieved from http://dx.doi.org/10.1080/13527258.2 011.643911

[44] Hinch, T., \& Higham, J. Sport tourism development (2nd ed.). Bristol: Channel View Publications, 2011

[45] Jarvie, G. Sport, culture and society: An introduction. London: Routledge, 2006. 